\title{
UK/European Co-productions: The Case of Ken Loach
}

\begin{abstract}
:
Ken Loach stands out as one of the few British directors whose films are regularly coproduced with European partners. Of the 19 films he has directed since 1990, 14 have been UK/European co-productions. This article draws on interviews with Loach's long-term producer Rebecca O'Brien, content analysis of his films and the statistical analysis of box office data to examine how and why Loach came to work with European co-production partners and how these partnerships have affected the cultural identity of his films and their box office performance. It argues that while some of Loach's co-production partnerships were initiated for creative reasons, most have proceeded on a 'finance-only' basis, whereby the partners have had very little creative input in his films. Co-production has therefore allowed Loach to continue making ‘culturally British' films without the creative interference which often comes with this mode of filmmaking. This creative freedom has been vital in terms of maintaining Loach's reputation as one of Europe's leading 'auteurs' and attracting the attention of film festivals like Cannes and Berlin, which in turn have played a key role in marketing his films and increasing their admissions in key European territories. Coproduction has also boosted the performance and circulation of Loach's films in mainland Europe by making it easier to access EU MEDIA distribution support. These findings not only offer new insights into Loach's films in terms of their production, content and reception, but also contribute to wider debates surrounding co-production and transnational cinema.
\end{abstract}

Keywords: Ken Loach; Rebecca O’Brien; co-production; transnational cinema; British film; Europe; MEDIA programme. 
Ken Loach is one of Britain's most acclaimed directors. After making his name in television in the 1960s with hard-hitting docudramas like Up the Junction (1965) and Cathy Come Home (1966), he branched out into filmmaking. In 1967, he directed his first feature film, Poor Cow (1967), and two years later he made the celebrated coming-of-age drama Kes (1969). While continuing to direct television dramas and documentaries, Loach's film output became more intermittent during the 1970s and 1980s partly because he struggled to secure funding. However, since the 1990s Loach's film career has enjoyed a revival. Between 1990 and 2014, he directed 19 feature-length films - an average of almost one per year - making him one of Britain's most prolific directors of recent times. ${ }^{1}$ In 2006, Loach won the prestigious Palme d'Or at Cannes for The Wind That Shakes the Barley (2006), and in 2014 he received the Honorary Golden Bear at the Berlin International Film Festival.

Much of the scholarship on Ken Loach has focused on his directorial style and the political ideas expressed within his films (for example see McKnight 1997; Fuller 1998; Leigh 2002; Hayward 2004; Hill 2011). Loach's approach to filmmaking is generally associated with social realism or naturalism - he often uses non-professional actors and employs methods drawn from documentary filmmaking - while politically he is known for his commitment to socialism. His films often focus on issues of social justice, labour rights, and the lives and struggles of the working-class. A recurrent theme within the literature has been whether Loach's progressive politics are helped or hindered by his naturalistic style of filmmaking (see Leigh (2002) for an overview of this debate).

A less analysed aspect of Loach's filmography is the production context in which his films are made. Key to Loach's prolific film output since the early 1990s has been his ability to secure funding through co-production with European partners. Of the 19 feature films he has made since 1990, 14 have been European co-productions [table 1]. Indeed, Loach is one of the few British directors whose films are regularly co-produced with other Europeans. 
John Hill's (2011: 163) recent study of Loach notes that funding from Europe has helped to underpin 'Loach's ability to sustain feature film-making on a regular basis during the 1990s and 2000s'. He also suggests that 'Loach's growing dependence upon Europe for funding, audiences and critical prestige has encouraged a degree of "internationalisation" of his concerns' (Hill 2011: 173). However, Hill's otherwise superb and comprehensive account does not go into any specific detail about how these funding arrangements were established or how they operated in practice.

This paper addresses this gap in the literature through offering a more detailed account of how and why Loach came to work with his European co-production partners and how these partnerships have affected his films. I focus in particular on Loach's most sustained relationships, firstly, with Spain's Tornasol Films and Germany’s Road Movies Production between the early 1990s and the late-2000s, and secondly, with France's Why Not Productions and Wild Bunch, which has lasted from the late-2000s up until the present date. I examine whether Loach's decision to work with these different European partners was driven by financial or creative concerns and whether it led to any cultural or artistic compromises. I also explore how these partnerships may have influenced the cultural identity of his films and their box office performance and circulation, particularly in Europe. The research - which is based on interviews with Loach's long-term producer, Rebecca O'Brien, content analysis of his films, and the statistical analysis of cinema admissions data - is intended not only to provide new insights into Loach's films in terms of their production, content and reception, but also contribute to wider debates surrounding co-production and transnational cinema. ${ }^{2}$

\section{Co-production and transnational relationships}

Before exploring Ken Loach's relationship with his European co-production partners, I want to begin by defining the term 'co-production' and outlining some of the key issues 
surrounding this mode of filmmaking. According to the British Film Institute (BFI), a coproduction is: 'A film made by companies from more than one country, often under the terms of a bilateral co-production treaty or the European Convention on Cinematographic Coproduction' (BFI 2014: 241). These may be 'majority' co-productions, 'in which the UK investment is the largest single national investment', or 'minority' co-productions, 'in which at least one other country made a larger investment than the UK' (BFI 2014: 182). Coproductions are distinguished from 'domestic features', films made by a UK production company that is 'produced wholly or partly in the UK', and 'inward investment features', which are 'substantially financed and controlled from outside the UK and which [are] attracted to the UK by script requirements (e.g. location) and/or the UK's filmmaking infrastructure and/or UK film tax relief' (BFI 2014: 242-3). The latter are similar to coproductions in the sense that they involve an international partnership between a British and foreign film company (usually a major Hollywood studio). ${ }^{3}$ However, there are important material and legal distinctions between the two. Firstly, as the phrase 'substantially financed and controlled' indicates, inward investment features are not usually recognised as 'independent' films (unlike either co-productions or domestic features). Secondly, with a few exceptions, inward investment features are generally made outside an official co-production treaty (which will specify the minimum level of creative and financial input each partner must contribute to the qualifying film). ${ }^{4}$ Thus, whereas official co-productions are classified as 'British' films regardless of their actual cultural content, inward investment features must pass a 'cultural test' in order to qualify for UK film tax relief or other subsidies. ${ }^{5}$

Morawetz et al. (2007) distinguish between three broad categories of co-production. Firstly, there are 'creatively-driven co-productions', which primarily come together for cultural reasons, such as a cross-border story (for example, a pan-European road movie). These are typically low-to-medium budget art-house films. Secondly, there are 'financially- 
driven co-productions', which are only structured as co-productions so the filmmakers can raise the necessary finances to get the picture made, even if this means adjusting the film's creative elements. These are also usually low-to-medium budget films financed on a one-off basis. Finally, there are 'capital-driven co-productions', where a film is structured as a coproduction largely to enable investors to exploit financial benefits like tax credits. These are typically medium-to-high budget films aimed at mainstream international audiences. They usually form part of a slate of films and are often distributed by Hollywood studios. Morawetz et al.'s notion of 'capital-driven co-productions' mainly refers to what the BFI calls 'inward feature co-productions'. These are a particular type of inward investment feature (in the sense that they are substantially financed and controlled by a major Hollywood studio) that have nevertheless been engineered as official co-productions in order to benefit from local tax incentives. ${ }^{6}$

Hjort (2009) offers a more complex schema for describing co-productions and other filmmaking practices that are structured through 'transnational relationships'. Some of these categories resemble those outlined by Morawetz et al. For example, Hjort's notion of 'opportunistic transnationalism' broadly corresponds with 'financially-driven' coproductions, while her concept of 'global transnationalism' equates with 'capital-driven' coproductions. Others categories offer a more nuanced way of thinking about 'creativelydriven' co-productions (or more specifically those co-productions which are not solely motived by monetary factors). For example, Hjort suggests transnational relationships can be 'affinitive' in the sense that they are underpinned by common values, cultures, practices and institutions; they may be 'epiphanic' in the sense that they seek to promote transnational identities; or they may be 'milieu-building' in the sense that they attempt to transfer successful filmmaking practices developed in one country to another. 
Research suggests that co-productions are more often financially-driven than creatively-driven. A survey of Canadian and European co-production partners in the 1990s by Hoskins et al. (1995), for example, found that the opportunity to pool financial resources was seen as the most important benefit, followed by access to foreign incentives and subsidies and access to the partner's market. By contrast, cultural goals, such as filming in a desired location, ranked relatively low on the list of priorities. Similarly, Pardo (2007: 22) calculates that the majority of co-productions made in Spain between 2000 and 2004 were 'designed on a strictly financial basis, without demanding necessarily a creative or cultural exchange'. Only a quarter could be described as 'multicultural co-productions in the proper sense of the term' (Pardo 2007: 22). My own analysis (Jones 2016) of a random sample of 30 recent UK/European co-productions likewise suggests that only a fifth involved any significant creative or cultural input from the European co-production partner(s).

But even though most co-productions are financially-driven, the logistics of coproduction may still have consequences for the film's cultural identity. Co-production agreements often require filmmakers to include transnational cultural elements in order to qualify for foreign funding, even if this is not necessarily appropriate to the film's narrative. Such cultural or artistic compromises have led some to associate co-productions with the derogatory term 'Europuddings' - films which unconvincingly blend together different cultural and linguistic elements or which downplay those differences, only to appear bland and indistinct (see Liz 2005). However, others suggest that the inclusion of transnational cultural elements may yield positive results. Jäckel (2007: 29), for example, notes in relation to the work of the Franco-German broadcaster Arte, co-production has resulted in “outstanding examples of European works addressing cultural diversity and the (problematic) integration of individuals, or groups of individuals, within a wider community". 
Co-production may also affect a film's box office performance. A report for the European Audiovisual Observatory by Kanzler (2008), for example, found that European coproductions sold 2.7 times more cinema tickets within the European Union (EU) than purely domestic features and were also released in twice as many territories. However, as I have argued elsewhere (Jones 2016), this is not necessarily because audiences are more attracted to films with transnational cultural elements, but rather because co-productions have bigger budgets than purely domestic features. Being able to pool financial resource and qualify for tax incentives in partner territories means that co-productions have more money to spend on stars, special effects, locations, marketing and other elements which attract audiences. Coproduction also leads to stronger links with foreign distributors and exhibitors, and makes it easier to access distribution subsidies. For example, $47 \%$ of UK/European co-productions received funding from the EU's MEDIA programme, which supports the circulation of nonnational European films, compared with only $29 \%$ for domestic UK features (Jones 2016). Thus, as Bondebjerg and Redvall (2013: 8) likewise note in relation to the regional circulation of Scandinavian co-productions, 'Co-production probably is an important factor for the internationalisation of films, but other elements such as genre, star quality and distribution play a central one'.

\section{Loach's early co-productions}

Loach made his first European co-production 35 years ago with Black Jack (1979), a children's period drama about a Yorkshire boy's adventures with an eighteenth century highwayman. After failing to raise adequate funding for the film in the UK, Loach's then producer Tony Garnett managed to secure money from French and West German sources. Loach's previous film, Family Life (1971), had performed well in France, and Garnett was keen to exploit this French interest. However, according to Hill (2011: 158), the use of 
French funding 'necessitated the casting of French actor Jean Franval' in the role of Black Jack, and led Garnett to 'regret making the film, feeling that it was the availability of funding rather than a full belief in the subject-matter that had led to his involvement'.

Loach's next European co-production was the Cold War drama Fatherland (1986), one of only two films Loach directed in the 1980s. The film tells the story of a German protest singer who swaps the political intimidation of East Berlin for the equally controlling capitalist music industry of the West. Like Black Jack, it involved French and West German co-production partners. But while the German partner was clearly required for creative reasons, the involvement of a French partner was again a financial decision which necessitated cultural compromises. For instance, the role of a Dutch journalist who helps the singer track down his expatriate father was taken by a French actress. More generally, Hill (1997: 127-130) suggests that the involvement of European funding may have affected the film's aesthetic style and, in turn, undermined its political impact. Firstly, in contrast to Loach's previous work, Fatherland offers what Hill calls a 'disengaged' or 'distanced' view of England, where the German singer goes to search for his father. As such, it 'fails to offer the opportunity for socio-political comment which the film otherwise seeks to make' and instead 'is dependent upon rather heavy-handed narrative insertions, rather than textured mise en scène, to deliver some kind of political perspective' (Hill 1997: 128). Secondly, the film employs conventions more associated with European art cinema than the British social realist tradition with which Loach's work is more usually associated. For example, 'unlike other Loach films, the central protagonist... is troubled, introspective and equivocal in a way more typical of the European art film' (Hill 1997: 128). It also uses 'expressionist techniques', such as temporal jumps, the introduction of dream and memory sequences, and the adoption of loosely Brechtian techniques, as in the use of titles, songs and music. According to Hill (1997: 129), these European art film conventions 'work against [the film's] political 
objectives, and its apparent concern with the limits of freedom in both the East and the West tends to become subordinate to a more general, more existential sense of malaise'.

\section{Working with Spanish and German partners}

If Black Jack and Fatherland represent early forays into the world of co-production, Loach's strategy of working with European partners only really emerged in the early-1990s with the Spanish Civil War drama Land and Freedom (1995). Produced by Parallax Pictures (the cooperative Loach established in 1981 with the producers Rebecca O'Brien, Sally Hibbin and Sarah Curtis, the director Les Blair and the actor and director Philip Davies), Land and Freedom tells the story of a young unemployed communist who in 1936 leaves his native Liverpool to join the fight against fascism in Spain. With most of the action taking place in Spain, there were obvious cultural and practical reasons to work with a Spanish partner. At the same time, producer Rebecca O'Brien suggests there was also a strong financial rationale for involving foreign co-production partners: "Because it was a period war film set in a different country, it was going to be more expensive than the films that... Ken had been making prior to that" (O’Brien 2014a). Its $£ 2.75$ million budget was beyond the means of Channel 4, who had financed Loach's last three films (Hayward 2004: 225), and the semipublic funding body British Screen, which only had an annual budget of $£ 1.5$ million (Hill 1999: 38). After a decade during which the Conservative government had cut film subsidies and emphasised economic self-sufficiency for the film industry (Hill 1999), domestic sources of film funding were becoming increasingly scarce. At the same time, new sources of international funding were becoming available. In the early 1990s, Britain signed the European Convention of Cinematographic Co-production, allowing British filmmakers to benefit from public subsidies and tax incentives in other European countries. The UK also 
became a member of Eurimages, the Council of Europe's co-production fund, though left after only four years due to government budget cuts (Dawtrey 1995).

Loach's colleagues at Parallax Pictures, Sally Hibbin and Sarah Curtis, sought out potential Spanish partners while promoting one of Loach's other films at the Valladolid Film Festival in Spain. They were introduced to Ulrich Felsberg of German-based Road Movies, who in turn put Hibbin and Curtis in touch with Gerardo Herrero of Madrid-based Tornasol Films. Parallax’s relationship with Road Movies and Tornasol could be described as an example of what Hjort (2009) calls 'affinitive transnationalism' in the sense that it was underpinned by common values. All three were a similar size, and they also shared a similar outlook in terms of producing auteur-driven films in their own countries (Road Movies, for example, handled Wim Wenders' slate). The relationship could also be described as 'mileubuilding' in the sense that Felsberg and Herrero were both much more familiar with coproduction and could guide their British partners through the process. Felsberg, for example, showed Parallax how to obtain money from the Nordrhein-Westfalen (NRW) regional film fund in return for buying all their lighting and camera equipment in Germany. Tornasol and Road Movies also provided 40 percent of the film's budget through securing television rights and theatrical pre-sales, as well as made it possible to acquire a further 15 percent of the budget from Eurimages, just prior to Britain leaving the scheme. Meanwhile, Parallax secured the remaining budget through television pre-sales to the $\mathrm{BBC}$ and a grant from British Screen, providing just enough money to get Land and Freedom made.

Aside from the challenge of negotiating different languages and legal practices, one of the initial teething problems Parallax Pictures faced was the question of how much creative input their co-production partners should have in the film. This came to a head when Tornasol passed Parallax on to a Catalan-based servicing company called Messidor Films, whose job was to provide local production support. As O’Brien explains: 
There was a tricky moment at the beginning when it wasn't quite clear what the role of the co-producers were [meant to be], and it then became clear that I had to make a point of saying, "Look, I'm the main producer. All the creative decisions have to go through me. We need your advice Messidor - thank you very much - in finding the right people to help us crew, but beyond that we will make those decisions". (O'Brien 2014a)

In retrospect, this intervention proved to be hugely significant, because it ensured that unlike Loach's earlier co-productions, Land and Freedom avoided cultural or artistic compromises.

The relationship with Tornasol and Road Movies continued for another 15 years after Land and Freedom, by which time Loach and O'Brien had left Parallax Pictures to form a new production company, Sixteen Films, with the screenwriter Paul Laverty. But while Loach continued to make films set wholly or partly abroad (for example Carla's Song, Bread and Roses and The Wind That Shakes the Barely), there was no longer a clear cultural rationale to continue working with Spanish or German partners. Nevertheless, Tornasol and Road Movies contributed to a further eight Loach films as 'finance-only' co-producers (each providing at least $10 \%$ of the budget). They were joined by several other European distributors, broadcasters and funding bodies - including Italy's BIM Distribuzione, Spain's Alta Films, Ireland's Element Films and Britain's Matador Pictures - who helped co-produce Loach's films on a more ad-hoc basis. While some of these partners certainly provided creative support where this was natural to the co-production (for example, Element's involvement in the Irish period drama The Wind That Shakes the Barley), most had little or no direct creative input in Loach's films. Yet this is not to suggest that there were no benefits for the minority co-production partners themselves. As O’Brien (2014a) explains, 'apart from 
the fact that they have actually some skin in the game', being recognised as a co-production partner meant they could access co-production support, distribution rights and pre-sales within their own country. 'They also have kudos of working of whoever the director might be and having their name attached to the film', she adds. At the same time, O'Brien acknowledges that she has not always been able to fully reciprocate the relationship with her European partners by facilitating access to UK distribution, tax relief and subsidies:

The distributors in Britain are really sniffy about European films.... I have never been able to co-produce a Spanish film in Britain by bringing a distributor to that project. Likewise [with] Germany. It's always been one-sided, and it's always been about the fact that their countries like the Ken Loach films [so] they keep up the relationship.... And also because we are not even in Eurimages we can't even give them that support. (O’Brien 2014b)

This echoes a similar point made by Mike Downey of the production company Film and Music Entertainment (F\&ME), who, in written evidence to the House of Lords Select Committee in 2010, noted that co-production with Europe only worked if the relationship was reciprocal, something he argues the UK film tax relief tends to discourage, because it only applies to goods and services 'used and consumed' in the UK (see House of Lords 2010).

\section{Working with French partners}

Sixteen Films eventually parted ways with their Spanish and German partners in the late2000s. The collapse of the Spanish cinema market due to increasing piracy and economic recession meant Tornasol could no longer bring adequate levels of funding to the table (O'Brien 2014a). The German market had also changed. Loach's films were performing less 
well in Germany, and, according to O'Brien (2014a), German film companies were becoming 'more interested in indigenous product'. The demands of the NRW regional film fund, the main source of German public money for Loach's films, that co-productions must spend at least $€ 1.50$ in the local region for every Euro of support they receive may have also made Germany a less attractive production partner (Cooke 2012: 37).

By this time, however, Sixteen Films had established a new relationship with France's Why Not Productions and Wild Bunch. This partnership again initially came about for creative reasons after the French footballer Eric Cantona approached Loach through the boss of Why Not, Pascal Caucheteux, with the idea for making a film to thank his British fans for supporting him through his eventful five year spell at Manchester United. The idea was developed by screenwriter Paul Laverty into the 2009 comedy Looking for Eric (2009), in which Steve Evets stars as a football fanatic postman who receives life coaching from Cantona after his life descends into crisis.

Why Not and Wild Bunch were obvious partners for Sixteen Films. France had long been Loach's most successful territory, with almost four times as many ticket sales on average than the UK itself. While Sixteen Films had always secured pre-sales from France through their French distributor Diaphana, the involvement of French co-production partners allowed them to directly access substantial amounts of public funds and television money (much to the disappointment of Diaphana, who up until that point had been able to keep these funds for themselves).

Sixteen Films' relationship with its French partners continued after Looking for Eric for another four films up until Loach's most recent production Jimmy's Hall (2014). ${ }^{7}$ As with Tornasol and Road Movies, the partnership proceeded on a finance-only basis, albeit involving a much higher level of financial commitment. In particular, Why Not were able to cash-flow Loach's films through using their own line of credit. For O’Brien (2014a): ‘That 
was music to my ears, because my big struggle always with putting together a sort of patchwork co-production was always where to get the cash flow from'. Why Not also took on the role of executive producer, using their contacts to secure extra funding and pre-sales, so leaving Sixteen Films to focus on the production itself. One new relationship Why Not helped establish was with Belgium's Les Films du Fleuve, the production house of the Dardenne brothers. While this was another finance-only partnership (enabling Sixteen Films to benefit from Belgian tax relief), it could be seen as another example of 'affinitive transnationalism' due to the clear parallels between Loach and the Dardennes in terms of their directorial style and commitment to addressing certain social and political issues.

\section{The cultural identity of Loach's films}

Loach has therefore co-produced his films with numerous European partners over the past 35 years. But while some of these partnerships have certainly been initiated for creative reasons (for example, Tornasol's involvement on Land and Freedom), most have operated on a 'finance-only' basis, whereby the co-production partners have had very little creative input. As producer Rebecca O’Brien confirms:

I always take seriously what the co-producers have to say about the script.... And again we'll invite them to see a screening when we've got a cut that we think we're nearly there with, so that they can have input.... But on the whole they trust us to get on with it. (O’Brien 2014a)

This is actually quite typical with UK/European co-productions. My own analysis (Jones 2016) of a random sample of 30 recent UK/European co-productions suggests most British filmmakers work with other Europeans for financial reasons. Only a fifth of the films 
analysed could be described as 'creatively-driven co-productions', where the partner has been clearly chosen for script requirements or other creative reasons.

If Loach has had very little creative input from his European co-production partners, neither has he been forced - with the exception of the early co-productions Black Jack and Fatherland - to make any significant cultural or artistic compromises in order to secure their funding. This can be attributed to several factors. Firstly, as we have seen, Loach's long-term producer Rebecca O'Brien has been able to resist any attempts to interfere with the creative process by making it clear early on that all creative decisions must go through her. Secondly, Loach's creative freedom has been underpinned by the fact that his films are not beholden to one single financier but instead rely on a patchwork of funding from different sources. As O'Brien told a recent industry event on co-production: 'It's basically about divide and rule.... You get as many people on board as possible so you can be in charge, because you can just dilute the executive power of commissioning editors' (Atlantic Film Festival 2013).

Finally, Loach has been under no legal obligation to actually include any creative input from his co-production partners. Since the early 1990s Loach's films have all been coproduced under the European Convention on Cinematographic Co-productions. While this agreement specifies that, 'In principle... the contribution of the co-producers relating to creative, technical and artistic personnel, cast and facilities, must be proportional to their investment,' it also allows 'finance-only co-productions' provided they meet the following conditions:

(a) include one or more minority contributions which may be financial only, in accordance with the co-production contract, provided that each national share is neither less than $10 \%$ nor more than $25 \%$ of the production costs; 
(b) include a majority co-producer who makes an effective technical and artistic contribution and satisfies the conditions for the cinematographic work to be recognised as a national work in his [sic] country;

(c) help to promote a European identity; and

(d) are embodied in co-production contracts which include provisions for the distribution of receipts.

(Council of Europe 1992)

Clause (b) - 'the cinematographic work to be recognised as a national work in [the majority co-producer's] country' - does not mean that the film needs to pass the British 'cultural test', since it already qualifies as 'British' as an official co-production. Likewise, with regard to clause (c) - 'help to promote a European identity' - a film qualifies as 'European’ only so far as the majority of its key creative and technical personnel (that is, the director, scriptwriter, composer, leading actors, cameraman, sound recordist, editor and art director) are European citizens and not because it involves cultural elements from different European countries.

But while Loach's co-production partners have had little creative input in his films, Hill (2011: 173) is right to point out that 'Loach's growing dependence upon Europe for funding audiences and critical prestige has encouraged a degree of 'internationalisation' of his concerns'. Of the 19 films Loach has directed since 1990, just under half have been partly or wholly set aboard, including Land and Freedom (set in Spain), Carla's Song (partly set in Nicaragua), Bread and Roses (set in the US), Tickets (set in Italy), The Wind That Shakes the Barley (set in Ireland), It's a Free World (partly set in Poland), Route Irish (partly set in Iraq), and Jimmy's Hall (set in Ireland). Many of Loach's British-set films also feature characters from other countries or ones with transnational cultural ties. Ae Fond Kiss... 
(2004), for example, focuses of the complex relationship between an Irish immigrant and a Scottish man of second-generation Pakistani heritage.

Nevertheless, almost all of the films Loach has made with European partners would still easily qualify as ‘culturally British' under the BFI's cultural test for film. Not only are they mostly made in Britain by a largely British cast and crew, but they also generally focus on British settings, characters and subject matter. The only films which might fail the test would be Tickets, Jimmy's Hall, and Bread and Roses - three films which are entirely set outside the UK with mainly non-British characters and cast. O'Brien (2014a) confirms that, 'we always tick enough boxes in the cultural test to qualify as British', but also suggests that Loach's films should be seen as both 'British' and 'European' in the sense that 'the stories that we tell are certainly relevant throughout Europe and often appreciated far more in parts of Europe than they are in the UK'. This echoes Hill's (2011: 173) point that the British elements within Loach's films may be seen to possess 'an international dimension by virtue of the common dimensions of working-class experience across different countries'.

Yet while most of his films could be described as 'culturally British', Loach could hardly be described as a flag-waving director. Indeed, he has even been accused of 'loathing his own country' by one right-wing critic (Dudley Edwards 2006). Four of Loach's most recent films (Carla's Song, My Name Is Joe, Sweet Sixteen, Ae Fond Kiss... and The Angel's Share) are set wholly or partly in Scotland, though even here the director attempts to destabilise dominant notions of Scottishness. The Angel's Share (2013), for example, pokes fun at the tourist image of Scotland by having a group of unemployed Glaswegian friends attempt to steal a precious brand of whiskey from a Highland distillery by siphoning it into empty bottles of Irn Bru, a drink popular with working-class Scots. Hill (2011: 182-3) notes that while "this Scottish "turn" could be partly explained by Loach's collaboration with Scottish writer Paul Laverty', it was 'no doubt encouraged by the increasing availability of 
public funding in Scotland as well', adding a further layer of complexity to the question of how funding has affected the cultural identity of Loach's films.

\section{The performance of Loach's films}

The fact that most of Loach's films could be described as 'culturally British' has not lessened their appeal outside Britain. Indeed, Loach's films often perform much better in mainland Europe than the UK itself. Analysis of data from the European Audiovisual Observatory's (2015) LUMIERE database suggests that $87 \%$ of the EU cinema admissions for Loach's films come from outside the UK. This compares with 55\% for the average UK domestic feature. Loach's most successful European territory has been France, where his films generate a (median) average of 351,288 admissions, followed by Italy (185,467 admissions), the UK (89,840 admissions) and Spain (88,305 admissions) [figure 1]. In terms of cinema admissions per head of population (or 'penetration rate'), Loach's films have also performed particularly well in Denmark (with a mean average penetration rate of $0.50 \%$ ), Luxembourg $(0.43 \%)$ and Switzerland $(0.43 \%)$, but also to a lesser extent in Iceland $(0.35 \%)$ and Belgium $(0.31 \%)$

How much of this success in mainland Europe can be directly attributed to the involvement of European co-production partners is difficult to gauge. Certainly there is evidence (for example Kanzler 2008) that European co-productions travel better than purely domestic features. Often this is because co-production partners help to facilitate better foreign distribution links (Jones 2016). However, in Loach's case, the evidence for this is mixed. On the one hand, Loach's films generally performed better than average in Spain during the period when his films were co-produced with Spain's Tornasol Pictures. O'Brien (2014a; 2014b) also suggests co-production made it easier to obtain funding from the EU's MEDIA programme, which aims to increase the circulation and viewership of European audiovisual 
works. During the period 2007 to 2013, Loach's films received over $€ 2.4$ million from the MEDIA programme to support the distribution of four films - the highest amount received by any British director (MEDIA Desk UK 2008-2014). On the other hand, Loach's films have tended to under-perform in the territory of their German partners Road Movies, while France was Loach's strongest territory long before the partnership with French partners Why Not and Wild Bunch was established in 2008.

What appears to make most difference to the box office performance of Loach's films is the critical reception of the work. It is noticeable, for example, that Loach's most successful film in box office terms has been The Wind That Shakes the Barley, which won the 2006 Palme d'Or at Cannes, while The Angel's Share, which won the Cannes Jury Prize in 2012, has been his second best performing film. By contrast, Route Irish, Tickets and Bread and Roses, which have received the lowest level of critical appreciation according to the Rotten Tomatoes website, have also been amongst Loach's worst performing films.

Co-production has therefore affected the performance of Loach's films only so far as it has allowed him to make high quality films without any creative interference from his coproduction partners. This creative freedom has been vital in terms of maintaining Loach's reputation as one of Europe's leading 'auteurs' and attracting the attention of film festivals like Cannes and Berlin, which in turn have played a key role in marketing his films (Mayne 2014). It has proved particularly important to his success in France, where there seems to be a well-developed audience for 'auteur' cinema. It is worth noting, for example, that figures from the LUMIERE database (2015) suggests that other recognised British 'auteurs' like Mike Leigh and Michael Winterbottom also tend to sell more cinema tickets in France than the UK itself. Creative freedom has also allowed Loach to address particular social and political issues. According to Leila Wimmer (2009: 197), Loach's social and political commitment helps explain his appeal in France, where he is seen as a welcome alternative to 
the 'self-centred' concerns of contemporary French auteur cinema, on the one hand, and the 'escapism' of more popular French cinema, on the other.

Yet it is important to point out that Loach's film have not been universally wellreceived across Europe. While in Western Europe they have an average penetration rate of $0.25 \%$ of the population, in Central and Eastern Europe their average penetration rate is only $0.04 \%$. Whether this is due to structural factors like the poor availability of cinemas or the low levels of disposable income or cultural factors such as a lack of affinity with British stories or social realist cinema is not clear (though it may also be due to poorer levels of data collection in this region). But it is worth noting that the only film to contain Polish cultural elements (It's a Free World...) did not do particularly well in Poland itself.

It is also worth pointing out that in comparison to countries like France and Italy, Loach's films have generally performed less well in the UK, though not quite as badly as many assume. O'Brien (2014b) notes that Loach's films do often perform better in the areas where they are made - the Scottish drama The Angels' Share, for example, played in mainstream cinemas in Scotland - but suggests British audiences may be suffering from what she calls 'Ken Loach fatigue'. She also suggest Loach may be 'too socialist' for conservative Middle England. However, where Loach's films have been shown in cinemas, they have generally performed better than most European countries. What has perhaps given the impression of box office underperformance is the fact that some of Loach's films - including The Navigators and It's a Free World...- were only released on television in the UK.

\section{Conclusion}

If Loach stands out as one of the few British directors whose films are regularly co-produced with European partners, this article has provided an account of how and why those coproduction partnerships were formed and how they have affected his films. By way of 
conclusion, I want to highlight some of the ways this research might also contribute to wider debates about co-production and transnational cinema. Firstly, Loach confirms that coproductions are often driven by financial rather than creative concerns. Although Loach's relationship with his Spanish partner Tornasol and his French partners Why Not and Wild Bunch were initiated for creative reasons, they continued on a finance-only basis, whereby the co-production partners had very little creative input in his films. However, these partnerships were not solely motivated by monetary factors. They could be seen as an example of what Hjort (2009) calls 'affinitive transnationalism' in the sense that they were underpinned by common values and outlook. They were also 'milieu-building' in the way that Tornasol and Road Movies helped to guide Loach's producer Rebecca O'Brien through the co-production process. They could even be described as 'epiphanic' in the sense that they gave expression to a common European identity. Consequently, unlike most financiallydriven co-productions, which often come together on a one-off basis, Loach's has continued to work with the same partners over several films.

Secondly, co-production does not necessarily lead to cultural or artistic compromises. While funding conditions forced Loach to make certain script adjustments with his early coproductions Black Jack and Fatherland, none of the co-productions he has made since Land and Freedom in 1995 have involved any creative interference. This is because Loach's producer Rebecca O'Brien has resisted attempts by co-production partners to interfere with the creative process. Loach's films have also relied on a patchwork of funding from different sources, and so has not been beholden to the demands of any one single financier. Equally important is the fact that Loach's films have been made under the European Convention of Cinematographic Co-production, which allows 'finance-only' co-productions in certain circumstances. Thus, while European funding has allowed Loach to make more films set aboard, most of his co-produced films could still be described as 'culturally British'. 
Finally, co-production can affect a film's box office performance. If Loach's films underperformed in the territory of his German partners Road Movies, they certainly performed above average in the territory of his Spain partners Tornasol. Moreover, coproduction made it easier for Loach's films to secure distribution support from the EU's MEDIA programme, which aims to increase the circulation of non-national European films. At the same time, co-production has boosted the performance of Loach's film only in so far as his partners have not interfered with the creative process. This creative freedom has been vital in terms of maintaining Loach's reputation as one of Europe's leading 'auteurs' and attracting the attention of film festivals like Cannes and Berlin, which in turn have played a key role in marketing his films and attracting audiences in key European territories, such as France, where there is a strong market for auteur cinema.

It is worth noting that Loach is not the only leading European director whose films are co-produced with other Europeans. Pedro Almodovar, Michael Haneke, Susanne Bier, Lars Von Trier and the Dardanne brothers (to name but a few) all make films with European partners. Many of the classics of post-war European cinema - including Fellini's La Dolce Vita, Visconti's Roco and his Brothers and Jean Luc Godard's Contempt - were also European co-productions (Jäckel 1996: 86). However, with the exception of Loach, few British auteurs have taken the opportunity to work with other Europeans. According to O’Brien (2014a; 2014b), potential European partners are often put off working with British filmmakers because of the fact Britain is not part of the Eurimages co-production fund. She also notes that the UK's film tax relief system discourages the production of films set in other European countries, because it only applies to goods and services 'used and consumed' in the UK. Thus, if the UK wants more filmmakers as prolific and critically acclaimed as Ken Loach, it needs to encourage better transnational links with Europe. 


\section{Acknowledgements}

This work comes out of the 'Mediating Cultural Encounters through European Screens' (MeCETES) project (www.mecetes.co.uk). MeCETES has received funding from the Humanities in the European Research Area (HERA) Joint Research Programme (www.heranet.info) [grant number 291827]. HERA is co-funded by AHRC, AKA, BMBF via PT-DLR, DASTI, ETAG, FCT, FNR, FNRS, FWF, FWO, HAZU, IRC, LMT, MHEST, NWO, NCN, RANNÍS, RCN, VR and The European Community FP7 2007-2013, under the Socio-economic Sciences and Humanities programme.

\section{Notes}

1. Loach also produced short films for the portmanteau feature 11'09'01 September 11 (2002) and Chacum son cinema/To Each His Own Cinema (2007), as well as directed the scenes within the documentary McLibel (2005).

2. The author conducted interviews with Loach's long-term producer, Rebecca O'Brien, at Sixteen Films' offices in London on 16 July 2014 and at the Making European Film and Television Conference in Ostend, Belgium, on 18 September 2014. The author has received permission to use extracts from these interviews.

3. Examples of UK inward investment features include the James Bond and Harry Potter franchises.

4. The BFI's definition of 'inward investment features' includes a small number of so-called 'inward feature co-productions', which are official co-productions that originate from outside the co-production treaty countries (usually the USA).

5. The cultural test is a points-based test where projects need to achieve 16 out of a possible 31 points to qualify as 'culturally British'. It comprises of four sections: cultural content 
(up to 16 points); cultural contribution (up to 4 points); cultural hubs (up to 3 points); and cultural practitioners (up to 8 points).

6. Examples of inward feature co-productions include Oliver Stone's Alexander (UK/France/Netherlands/USA 2004) and Ridley Scott's Kingdom of Heaven (UK/Germany/Spain/USA 2005).

8. At the time of writing, Loach is currently shooting I, Daniel Blake (2016). The film, which is due for released in summer 2016, is a Sixteen Films, Why Not and Wild Bunch production made with the support of the BFI and BBC Films. 


\section{References}

Atlantic Film Festival (2013), ‘SP 2012: Keynote - A conversation with Rebecca O’Brien', available at <https://www.youtube.com/watch?v=dYOIppdh1Pw> (accessed 18 May 2015).

Bondebjerg, Ib and Redvall, Eva Norvup (2013), 'Transnational Scandinavia? Scandinavian film culture in a European and global context', in Manuel Palacio and Jörg Türschmann (eds.), Transnational Cinema in Europe, Vienna: Universität Wien, pp.127-146.

British Film Institute (2014), Statistical Yearbook 2014. Available at <http://www.bfi.org.uk/statisticalyearbook2014/> (accessed 18 May 2015).

Cooke, Paul (2012), Contemporary German Cinema, Manchester: Manchester University Press.

Council of Europe (1992), European Convention on Cinematographic Co-Production. Available at <http://conventions.coe.int/Treaty/en/Treaties/Html/147.htm> (accessed 18 May 2015).

Dawtrey, Adam (1995), 'Government withdraws from Eurimages UK', Variety, 4-10 December. Available at < http://variety.com/1995/scene/markets-festivals/gov-twithdraws-from-eurimages-99123504/> (accessed 18 May 2015).

Dudley Edwards, Ruth (2006), 'Why does Ken Loach loathe his county so much?', Daily Mail, 30 May. Available at http://www.dailymail.co.uk/news/article-388256/Whydoes-Ken-Loach-loathe-country-much.html (accessed 18 May 2015).

European Audiovisual Observatory (2015), LUMIERE Database on Admissions of Films Released in Europe. Available at < http://lumiere.obs.coe.int/web/search/> (accessed 18 May 2015).

Fuller, Graham (ed.) (1998), Loach on Loach, London: Faber and Faber. 
Hayward, Anthony (2004), Which Side Are You On? Ken Loach and His Films, London: Bloomsbury.

Hill, John (1997), 'Finding a form: politics and aesthetics in Fatherland, Hidden Agenda and Riff-Raff', in George McKnight (ed.), Agent of Challenge and Defiance: The Films of Ken Loach, Westport, CT: Praeger Publishers, pp.125-143.

Hill, John (1999), British Cinema in the 1980s, Oxford: Clarendon Press.

Hill, John (2011), Ken Loach: The Politics and Film and Television, London: British Film Institute.

Hjort, Mette (2009), “On the plurality of cinematic transnationalism', in Nataša Durovicová and Kathleen Newman (eds.), World Cinemas, Transnational Perspectives, New York: Routledge, pp.12-33.

Hoskins, Colin, McFadyen, S., Finn, A. and Jäckel, A (1995), 'Film and television coproduction: evidence from Canadian-European experience', European Journal of Communication 10: 2, pp.221-243.

House of Lords Select Committee on Communication (2010), The British Film and Television Industries - Decline or Opportunity? Volume II: Evidence (HL Paper 37-II), London: Stationary Office.

Jäckel, Anne (1996), 'European co-production strategies: the case of France and Britain', in Albert Moran (ed.), Film Policy: International, National and Regional Perspectives, Abingdon: Routledge, pp.85-100.

Jäckel, Anne (2007), ‘The inter/nationalism of French film policy', Modern \& Contemporary France 15:1, pp.21-36.

Jones, Huw David (2016), 'The cultural and economic implications of UK/European coproduction', due for publication in Transnational Cinemas in May 2016. 
Kanzler, Martin (2008), 'The circulation of European co-productions and entirely national films in Europe 2001 to 2007', report prepared for the Council of Europe Film Policy Forum co-organised by the Council of Europe and the Polish Film Institute, Krakow, 11-13 September 2008. Available at <http://www.coe.int/t/dg4/cultureheritage/culture/film/paperEAO_en.pdf> (accessed 18 May 2015).

Leigh, Jacob (2002), The Cinema of Ken Loach: Art in the Service of the People, London: Wallfower Press.

Liz, Mariana (2015), 'From co-production to the Euro-pudding', in Mary Harrod, Mariana Liz and Alissa Timoshkina (eds.), The Europeanness of European Cinema: Identity, Meaning, Globalization, London: I. B. Tauris, pp.73-86.

Macnab, Geoffrey (2013), 'UK industry cheers tax break changes', Screen Daily, 5

December. Available at <http://www.screendaily.com/territories/uk-ireland/ukindustry-cheers-tax-break-changes/5064369.article> (accessed 18 May 2015).

Mayne, Laura (2014), Channel 4 and British Film: An Assessment of Industrial and Cultural Impact, 1982-1998, unpublished PhD thesis, University of Portsmouth.

McKnight, George (ed.) (1997), Agent of Challenge and Defiance: The Films of Ken Loach. Trowbridge: Flicks Books.

MEDIA Desk UK (2008), MEDIA in the UK 2007, London: MEDIA Desk UK MEDIA Desk UK (2009), MEDIA in the UK 2008, London: MEDIA Desk UK MEDIA Desk UK (2010), MEDIA in the UK 2009, London: MEDIA Desk UK MEDIA Desk UK (2011), MEDIA in the UK 2010, London: MEDIA Desk UK MEDIA Desk UK (2012), MEDIA in the UK 2011, London: MEDIA Desk UK MEDIA Desk UK (2013), MEDIA in the UK 2012, London: MEDIA Desk UK MEDIA Desk UK (2014), MEDIA in the UK 2013, London: MEDIA Desk UK 
Morawetz, Norbert, Hardy, J., Haslam, C. and Randle, K. (2007), 'Finance, policy and industrial dynamics - The rise of co-productions in the film industry', Industry and Innovation 14:4, pp.421:443.

O’Brien, Rebecca (2014a), Interview by author, Sixteen Films, London, 16 July.

O’Brien, Rebecca (2014b), Interview by author, Making European Film and Television Drama Conference, Ostend, Belgium, 18 September.

Pardo, Alejandro (2007), 'Spanish co-productions: commercial need or common culture? An analysis of international co-productions in Spain from 2000 to 2004', in Sandra Barriales-Bouche and Marjorie Attingnol Salvodon (eds.), Zoom Out: Crossing Borders in Recent European Cinema, Newcastle: Cambridge Scholar Publishing, pp.89-127.

Wimmer, Leila (2009), Cross-Channel Perspectives: The French Reception of British Cinema, Bern: Peter Lang AG. 